\title{
Control of Viral Contamination of Food and Environment
}

\author{
Dean O. Cliver
}

Received: 30 September 2008/ Accepted: 11 December 2008/Published online: 24 December 2008

(C) The Author(s) 2008. This article is published with open access at Springerlink.com

\begin{abstract}
Viruses are often transmitted via food and the environment. Contamination may be controlled either by preventing its occurrence or by inactivating the contaminating virus. The majority of agents transmitted in this way are human enteric viruses, produced either in the intestines or the liver. They are shed in human feces (noroviruses also in vomitus) in a broad range of circumstances, and they are relatively stable outside the host. Non-enteric viruses are less often transmitted via foods and are generally less environmentally stable. Insofar as vaccines are available, they are able to prevent fecal shedding. Viruses shed in feces via the water-carriage toilet may be eliminated by proper treatment and disinfection of the wastewater. In the foods context, the most effective antiviral measures are cooking and hand washing. Detection methods are most useful after the fact, in investigating outbreaks and devising preventive measures.
\end{abstract}

Keywords Enteric viruses - Hepatitis viruses .

Noroviruses · Virus detection · Virus inactivation

\section{Introduction}

Virus transmission via food and the environment is now a well-recognized problem. An extensive literature has accumulated on the subject (Cliver et al. 2006; Koopmans et al. 2008). This review is a brief overview of available

\section{O. Cliver $(\bowtie)$}

Department of Population Health and Reproduction,

School of Veterinary Medicine, University of California, Davis,

One Shields Avenue, Davis, CA 95616-8743, USA

e-mail: docliver@ucdavis.edu

URL: http://faculty.vetmed.ucdavis.edu/faculty/docliver/ control measures, based on epidemiological and laboratory studies. It appears that the majority of viruses transmitted to humans via food and the environment are of human enteric origin, so preventing fecal contamination constitutes the first line of defense, but further defense measures in the event of fecal contamination will be discussed. A few non-enteric viruses will also be considered.

\section{Enteric Viruses}

Viruses shed in feces may have been produced in the small intestine (Widdowson and Vinjé 2008) or in the liver with drainage into the intestine via the bile (Aggarwal and Naik 2008). Since feces may present other health threats in addition to viruses, one might hope to contain them as near to their source as possible. However, practical considerations such as their value in enhancing soil quality may preclude this.

\section{Human}

In some of the poorer parts of the world, the nutrients in human urine and feces are essential to food production. More affluent nations may prefer alternatives, but "night soil" fertilization represents the ultimate in sustainable agriculture. There are certainly some health risks from recycling waste; however, in sufficiently isolated communities, herd immunity may afford protection against many bacteria and viruses, though not against parasites. As communities grow and involvement in food production decreases, there is likely to be an informal phase of waste disposal, such as emptying slop jars out of second-story windows as was done in cities long ago (cf. gardyloo in many English-language dictionaries). This clearly entails a 
threat to public health; bacterial diseases spread in this way, such as typhoid and cholera, apparently obscured the risk of virus transmission. There are now options for dealing with human waste, close to the point of origin (onsite treatment), for isolated households and very small communities (Crites and Tchobanoglous 1998). These may have significant capital costs, but provide the best available alternative with limited means at hand.

With the current commitment to water-carriage toilets, larger communities are obliged to provide sanitary sewer systems. These were once designed simply to carry liquid waste away from the households of origin, but communities have recently been obliged consider the environmental and public health impacts of their waste disposal. Cities discharging to tide waters or rapidly flowing streams were formerly satisfied to see their waste go away. Now inland and most coastal cities treat their wastewater to the secondary or even tertiary level and disinfect it before discharge. Problems are arising with the adequacy of water supplies for this purpose, the need to recycle water that has been used, and the adequacy of current wastewater treatment technologies to control viruses, as well as the bacteria for which the processes were designed (Payment et al. 2001).

Controlling viruses in waste from large sedentary populations is certainly a challenge; however, the increasing mobility of humans results in generation of significant quantities of waste aboard conveyances. Such conveyances include trains, ships, motor vehicles, airplanes, and even spacecraft. In most instances, such wastes are contained and emptied for treatment at destination. There have been problems with ships discharging waste or waste-contaminated ballast water at or close to shore and with dock facilities that discharged human waste to the water (Roos 1956). Regulations abound but are difficult to enforce. At least, one hears of fewer instances of aircraft waste falling from the sky in recent years.

\section{Animal}

Animal manures may contain a variety of zoonotic pathogens, but few viruses are apparently transmissible to humans in this way (Cliver et al. 2006; Cliver and Moe 2004). Detection of animal enteroviruses may serve to demonstrate problems with run-off into waterways, but these viruses are seldom a direct threat to human health. Hepatitis E virus may sometimes be transmitted to humans by swine manure, but the main source appears to be raw porcine liver (Aggarwal and Naik 2008). Tick-borne encephalitis virus is transmitted zoonotically only via the milk of infected animals (Grešiková 1994). Zoonotic transmission of the SARS agent, during the outbreak that occurred in 2002-2003, is still an open question (Bell et al. 2004; Duizer and Koopmans 2008); the virus was detected in human sewage (Wang et al. 2005a, b). Transmission of avian influenza virus via food has not been demonstrated, but remains a possibility (Duizer and Koopmans 2008).

Stability

A common property of enteric viruses is their relative stability outside the host. They typically withstand $\mathrm{pH} 3$ for periods of time, which allows them to pass through the stomach (Duizer et al. 2004); however, this is not an absolute necessity, as some highly efficient bacterial pathogens infect perorally without acid stability. Viruses cannot multiply in the environment but they persist for days to months over a range of temperatures and are preserved by refrigeration or freezing. Some (notably the noroviruses and hepatitis A virus) withstand air drying (Appleton 2000; Mbithi et al. 1991).

\section{Non-Enteric Viruses}

The majority of viruses that infect humans are transmitted by other than fecal-oral means. These will be surveyed briefly here (Cliver and Moe 2004; Heymann 2004).

\section{Respiratory}

A great many viruses are transmitted by the respiratory route, including those that cause respiratory ailments (rhinoviruses, influenza and parainfluenza viruses, coronaviruses), as well as the formerly common childhood diseases (chickenpox, measles, mumps, varicella). Most appear to be transmitted in aerosols over short distances or by contact and not to persist in the environment for long. An exception is the adenoviruses, which often cause respiratory or eye infections but may be shed in feces (types 40 and 41) and are sometimes transmitted in swimming pool water. Smallpox, which has hopefully been eradicated, was transmitted by the respiratory route and was very persistent in the dry state on surfaces. The SARS virus, which has not been heard from lately, persists rather well in the environment (Rabenau et al. 2005). The avian influenza virus, on the other hand, is apparently quite labile (Forster et al. 2008).

\section{Vector-Borne}

Several encephalitides, as well as yellow fever, are transmitted by mosquitoes. These are not generally thought to be transmitted through the environment without vectors, but I have a personal recollection that some of the viral encephalitides were regarded as potential biological warfare agents, during my year (1961-1962) in the US Army 
Biological Laboratories, Fort Detrick, Maryland. Tickborne encephalitis will be mentioned under zoonoses.

\section{Venereal}

Venereally transmitted viruses tend not to be shed from the digestive tract. Some are probably shed in urine; but indirect, environmental transmission seems unlikely, with the possible exception of deposits on toilet seats (Joseph 1992). HIV-positive persons are permitted to handle food in the US, except at times when they are suffering from gastroenteritis.

\section{Zoonoses}

As was stated earlier, hepatitis E virus may sometimes be transmitted to humans who eat raw porcine liver (Aggarwal and Naik 2008). This may be a strain-specific property, in that hepatitis $\mathrm{E}$ virus is highly prevalent in US swine, but relatively rare among Americans in contact with the infected animals and in consumers. Studies on this question are continuing. Dairy animals infected with tick-borne encephalitis virus transmit the virus to humans via raw milk and products made with raw milk (Grešiková 1994). This, too, is not a universal property-not all tick-borne encephalitis viruses are known to be transmissible in this way; the majority of human infections result from tick bites. Milk and meat of infected animals have long been feared sources of rabies virus; for some reason, experiments to determine whether rabies virus can occur in these foods evidently have not been done. The SARS and avian influenza viruses were mentioned earlier.

\section{Prevention}

Given that the great majority of viruses transmitted to people via food or water emanate from the human intestines, a first question is, "How can human waste be contained and processed so as not to be the means of transmitting human viruses?" There are three major modes by which viruses in human feces may be transmitted to other people: (1) via unwashed hands-directly, as well as indirectly, via food or environmental surfaces touched by unwashed hands; (2) via casual disposal of contaminated human feces to soil or water; (3) by disposal of contaminated feces via the water-carriage toilet (common in most developed countries), followed by inadequate treatment of the wastewater. Good manufacturing practices and the hazard analysis-critical control points (HACCP) system are probably useful, but critical control points designed specifically to preclude or eliminate viral hazards are scarce at this time.
Hand Washing

A few studies of hand washing for virus removal have been reported (Ansari et al. 1989; Bidawid et al. 2000a, b; Bidawid et al. 2004; Cliver and Kostenbader 1984; Mbithi et al. 1992; Mbithi et al. 1993; Sattar and Ansari 2002). In general, it appears that reasonably diligent conventional hand washing will substantially eliminate the risk of transmitting virus from fecally contaminated fingers, either to other people, to food, or to environmental surfaces. Experimental conditions in each of these studies were necessarily established for consistency and reproducibility, so they could not possibly subsume all possible variations in human behavior.

\section{Environmental Inactivation}

Virus in casually disposed feces or in the untreated wastewater is subject to slow inactivation by physical, chemical, and biological effects. Virus may be shed in association with coproantibody, as well as with fecal solids (Cliver and Kostenbader 1979). Virions may associate with soil particles; some viruses have more than one isoelectric point (Mandel 1971). The rate of virus inactivation at or below $30^{\circ}$ depends on the $\mathrm{pH}$ and the ionic composition of the aqueous environment (Salo and Cliver 1976). The changes that result in loss of infectivity under these conditions have not been well documented. An early study suggested that the target of low-temperature inactivation was principally the RNA (Dimmock 1967), but it has been shown more recently that some virus inactivated at lowtemperature loses its ability to attach to host cell receptors, which implies a subtle denaturation of the coat protein (Nuanualsuwan and Cliver 2003). It would be especially useful to know how noroviruses are inactivated under these conditions, in that present methods of norovirus detection typically do not distinguish infectious from inactivated virus (Hewitt and Greening 2006; Nuanualsuwan and Cliver 2002).

In certain contexts, bacteria are able to attack and inactivate human enteric viruses; some, but not all, such attacks appear to entail enzymatic action on the capsid (Cliver and Herrmann 1972; Deng and Cliver 1992; Deng and Cliver 1995a; Deng and Cliver 1995b). Some bacteria produce low molecular weight substances that apparently inactivate viruses (Deng and Cliver 1995a). Other bacteria appear to use viral capsid protein as substrate (Herrmann et al. 1974).

\section{Waste Treatment}

For feces disposed appropriately via a water-carriage toilet, the focus is on the adequacy of wastewater treatment to 
remove or inactivate virus. The distinction between removal and inactivation is critical, in that removal typically entails retention of the virus in the solid fraction generated in wastewater treatment, which eventually must also be disposed. Urban wastewater treatment typically includes grit separation, primary sedimentation, secondary biological treatment, various optional tertiary treatments, and terminal disinfection. Grit may be treated as mineral matter; it should be expected to include viruses. Primary sludge and waste activated (or other biological) sludge are typically dewatered, blended, and digested before disposal. There is considerable information regarding virus destruction in this phase (Berg et al. 1988; Bertucci et al. 1977; Brashear and Ward 1983; Fenters et al. 1979; Ward and Ashley 1977a; Ward and Ashley 1977b; Ward and Ashley 1977c; Ward and Ashley 1978; Ward et al. 1976), and viruses have been shown to be biodegradable (Cliver and Herrmann 1972; Ward 1982; Ward and Ashley 1977b). Both urban wastewater biosolids and sludge from septic tanks or other on-site wastewater treatment appliances must be disposed with caution. Virus that has not been removed from or inactivated in the liquid phase must be controlled by terminal disinfection. Whether a chemical, such as chlorine or ozone, or UV is applied at this point, virus inactivation will be complete only if the wastewater has been adequately treated and the disinfectant dose is sufficient (Hajenian and Butler 1980; Hartemann et al. 1983; Olivieri et al. 1983; Tree et al. 1997; Warriner et al. 1985). Carry-over solids, and even some solutes, can interfere with disinfection (Babich and Stotzky 1980).

\section{Disinfection}

Antiviral disinfection is needed in other contexts as well. Drinking water is typically treated to remove extraneous matter and then disinfected before distribution. Food-contact surfaces, and even food surfaces, may require disinfection. Food-processing water is often reused, and may be disinfected with difficulty (Mariam and Cliver 2000a). Viruses are most susceptible to strong oxidizing agents and UV; ionizing radiation does not appear to be an option because the size of viral target is so small (DiGirolamo et al. 1972; Harewood et al. 1994; House et al. 1991).

\section{Cooking}

If food cannot be reliably disinfected before serving, adequate cooking becomes the critical control point. Many studies have shown, for example, that depuration of viruscontaminated shellfish is highly unreliable (Abad et al. 1997; Croci et al. 1999; Croci et al. 2005; DiGirolamo et al. 1975; McDonnell et al. 1997; Power and Collins 1989;
Power and Collins 1990), so those who choose to eat shellfish raw are at considerable risk. Thorough cooking of shellfish eliminates this risk, though at some gastronomic price (Croci et al. 1999; Croci et al. 2005; DiGirolamo et al. 1970; McDonnell et al. 1997). Cooking of other foods has also been shown to inactivate viruses (Baert et al. 2008; Feagins et al. 2008; Mishu et al. 1990; Pagliaro et al. 1995). However, conventional pasteurization of milk apparently does not inactivate hepatitis A virus completely (Bidawid et al. 2000a, b; Mariam and Cliver 2000b). Much remains to be learned about thermal inactivation of viruses in foods.

\section{Immunization}

The enteric viruses against which successful vaccines have been developed to date are the polioviruses, hepatitis A virus, and rotaviruses. These vaccines could enable eradication of poliomyelitis and hepatitis A from the earth, given sufficient resources and political will, since the viruses essentially infect only humans. If all food handlers were immunized, at the least they would not be potential sources of food contamination. However, hepatitis A immunization is costly and requires two doses at least 6 months apart; worker turnover in some segments of the food industry is too great to ensure that the two-shot series will be completed. Some state governments in the United States require hepatitis A immunization of food handlers, regardless of problems.

\section{Detection}

Detection of viruses in environmental samples, including food and water, was first derived from the available clinical diagnostic methods (Cliver 2008). Cell culture infectivity was a mainstay for a very long time, but it was eventually established that available host cell systems did not support replication of noroviruses and most strains of hepatitis A and $\mathrm{E}$ viruses. The advent of reverse transcription-polymerase chain reaction (RT-PCR) has changed the situation greatly. The RT-PCR is now a first line of diagnostic testing, and is also applied to food and environmental samples (Widdowson and Vinjé 2008). With added sequencing of amplicons, important epidemiologic associations can be established. The concern about RT-PCR detection, as applied to food and environmental samples but not to clinical specimens, is the general inability to determine whether the detected virus was infectious at the time of sampling. All the same, the ability to detect these viruses by RT-PCR (including real-time RT-PCR, or by microarrays) is of great importance in outbreak investigation and may provide information that is useful in devising preventive measures. 


\section{Summary}

The majority of microbial agents transmitted to people via food and the environment are human enteric viruses, produced either in the intestines or the liver. They are shed in human feces (noroviruses also in vomitus) in a broad range of circumstances, and they are relatively stable outside the host. Contamination may either be controlled by preventing its occurrence or by inactivating the contaminating virus. Non-enteric viruses are less often transmitted via foods and are generally less environmentally stable. A few available vaccines are able to prevent fecal shedding but are not yet fully exploited. Viruses in casually disposed feces undergo slow inactivation in the environment, either by physical loss of ability to infect or through microbial action. Viruscontaining feces disposed via the water-carriage toilet may be eliminated by proper treatment and disinfection of the wastewater. The most effective antiviral measures applicable to foods are cooking and hand washing. Detection methods are more useful after the fact, in investigating outbreaks and devising preventive measures, than as preemptive means to preclude transmission.

Acknowledgment This review was derived from a presentation to the COST 929 Symposium: "Current Developments in Food and Environmental Virology," in Pisa, Italy, on 11 October 2008.

Open Access This article is distributed under the terms of the Creative Commons Attribution Noncommercial License which permits any noncommercial use, distribution, and reproduction in any medium, provided the original author(s) and source are credited.

\section{References}

Abad, F. X., Pinto, R. M., Gajardo, R., \& Bosch, A. (1997). Viruses in mussels: Public health implications and depuration. Journal of Food Protection, 60, 677-681.

Aggarwal, R., \& Naik, S. (2008). Enterically transmitted hepatitis. In M. P. G. Koopmans, D. O. Cliver, \& A. Bosch (Eds.), Foodborne viruses: Progress and challenges (pp. 65-85). Washington, DC: ASM (American Society for Microbiology) Press.

Ansari, S. A., Sattar, S. A., Springthorpe, V. S., Wells, G. A., \& Tostowaryk, W. (1989). In vivo protocol for testing efficacy of hand-washing agents against viruses and bacteria: Experiments with rotavirus and Escherichia coli. Applied and Environmental Microbiology, 55, 3113-3118.

Appleton, H. (2000). Control of food-borne viruses. British Medical Bulletin, 56, 172-183.

Babich, H., \& Stotzky, G. (1980). Reductions in inactivation rates of bacteriophages by clay minerals in lake water. Water Research, 14, 185-187.

Baert, L., Uyttendaele, M., Van Coillie, E., \& Debevere, J. (2008). The reduction of murine norovirus $1, B$. fragilis HSP40 infecting phage B40-8 and E. coli after a mild thermal pasteurization process of raspberry puree. Food Microbiology, 25, 871-874.

Bell, D., Roberton, S., \& Hunter, P. R. (2004). Animal origins of SARS coronavirus: Possible links with the international trade in small carnivores. Philosophical Transactions of the Royal Society of London B Biological Sciences, 359, 1107-1114.

Berg, G., Sullivan, G., \& Venosa, A. D. (1988). Low-temperature stability of viruses in sludges. Applied and Environmental Microbiology, 54, 839-841.

Bertucci, J. J., Lue-Hing, C., Zenz, D., \& Sedita, S. J. (1977). Inactivation of viruses during anaerobic sludge digestion. Journal-Water Pollution Control Federation, 49, 1642-1651.

Bidawid, S., Farber, J. M., \& Sattar, S. A. (2000a). Contamination of foods by food handlers: Experiments on hepatitis A virus transfer to food and its interruption. Applied and Environmental Microbiology, 66, 2759-2763.

Bidawid, S., Farber, J. M., Sattar, S. A., \& Hayward, S. (2000b). Heat inactivation of hepatitis A virus in dairy foods. Journal of Food Protection, 63, 522-528.

Bidawid, S., Malik, N., Adegbunrin, O., Sattar, S. A., \& Farber, J. M. (2004). Norovirus cross-contamination during food handling and interruption of virus transfer by hand antisepsis: Experiments with feline calicivirus as a surrogate. Journal of Food Protection, 67, 103-109.

Brashear, D. A., \& Ward, R. L. (1983). Inactivation of indigenous viruses in raw sludge by air drying. Applied and Environmental Microbiology, 45, 1943-1945.

Cliver, D. O. (2008). Historic overview of food virology. In M. P. G. Koopmans, D. O. Cliver, \& A. Bosch (Eds.), Food-borne viruses: Progress and challenges (pp. 1-28). Washington, DC: ASM (American Society for Microbiology) Press.

Cliver, D. O., \& Herrmann, J. E. (1972). Proteolytic and microbial inactivation of enteroviruses. Water Research, 6, 797-805.

Cliver, D. O., \& Kostenbader, K. D., Jr. (1979). Antiviral effectiveness of grape juice. Journal of Food Protection, 42, 100-104.

Cliver, D. O., \& Kostenbader, K. D., Jr. (1984). Disinfection of virus on hands for prevention of food-borne disease. International Journal of Food Microbiology, 1, 75-87.

Cliver, D. O., Matsui, S. M., \& Casteel, M. (2006). Infections with viruses and prions. In H. P. Riemann \& D. O. Cliver (Eds.), Foodborne infections and intoxications (3rd ed., pp. 367-448). London, Amsterdam: Academic Press (Elsevier).

Cliver, D. O., \& Moe, C. L. (2004). Prospects of waterborne viral zoonoses. In J. A. Cotruvo, A. Dufour, G. Rees, J. Bartram, R. Carr, D. O. Cliver, G. F. Craun, R. Fayer, \& V. P. J. Gannon (Eds.), Waterborne zoonoses: Identification, causes and control (pp. 242-254). London: IWA (International Water Association Publishing).

Crites, R. W., \& Tchobanoglous, G. (1998). Small and decentralized wastewater management systems. Boston: WCB/McGraw-Hill.

Croci, L., Ciccozzi, M., De Medici, D., Di Pasquale, S., Fiore, A., Mele, A., et al. (1999). Inactivation of hepatitis A virus in heattreated mussels. Journal of Applied Microbiology, 87, 884-888.

Croci, L., De Medici, D., Di Pasquale, S., \& Toti, L. (2005). Resistance of hepatitis A virus in mussels subjected to different domestic cookings. International Journal of Food Microbiology, 105, 139-144.

Deng, M. Y., \& Cliver, D. O. (1992). Inactivation of poliovirus type 1 in mixed human and swine wastes and by bacteria from swine manure. Applied and Environmental Microbiology, 58, 20162021.

Deng, M. Y., \& Cliver, D. O. (1995a). Antiviral effects of bacteria isolated from manure. Microbial Ecology, 30, 43-45.

Deng, M. Y., \& Cliver, D. O. (1995b). Persistence of inoculated hepatitis A virus in mixed human and human wastes. Applied and Environmental Microbiology, 61, 87-91.

DiGirolamo, R., Liston, J., \& Matches, J. (1970). Survival of virus in chilled, frozen, and processed oysters. Applied Microbiology, 20, $58-63$. 
DiGirolamo, R., Liston, J., \& Matches, J. (1972). Effects of irradiation on the survival of viruses in west coast oysters. Applied Microbiology, 24, 1005-1006.

DiGirolamo, R., Liston, J., \& Matches, J. (1975). Uptake and elimination of poliovirus by west coast oysters. Applied Microbiology, 29, 260-264.

Dimmock, N. J. (1967). Differences between the thermal inactivation of picornaviruses at "high" and "low" temperatures. Virology, $31,338-353$.

Duizer, E., Bijkerk, P., Rockx, B., De Groot, A., Twisk, F., \& Koopmans, M. (2004). Inactivation of caliciviruses. Applied and Environmental Microbiology, 70, 4538-4543.

Duizer, E., \& Koopmans, M. (2008). Emerging food-borne viral diseases. In M. P. G. Koopmans, D. O. Cliver, \& A. Bosch (Eds.), Food-borne viruses: Progress and challenges. Washington, DC: ASM (American Society for Microbiology Press).

Feagins, A. R., Opriessnig, T., Guenette, D. K., Halbur, P. G., \& Meng, X. J. (2008). Inactivation of infectious hepatitis E virus present in commercial pig livers sold in local grocery stores in the United States. International Journal of Food Microbiology, 123, 32-37.

Fenters, J., Reed, J., Lue-Hing, C., \& Bertucci, J. (1979). Inactivation of viruses by digested sludge components. Journal-Water Pollution Control Federation, 51, 689-694.

Forster, J. L., Harkin, V. B., Graham, D. A., \& McCullough, S. J. (2008). The effect of sample type, temperature and RNAlater on the stability of avian influenza virus RNA. Journal of Virological Methods, 149, 190-194.

Grešiková, M. (1994). Tickborne encephalitis. In Y. H. Hui, J. R. Gorham, K. D. Murrell, \& D. O. Cliver (Eds.), Foodborne disease handbook: vol. 2. Diseases caused by viruses, parasites, and fungi (pp. 113-135). New York: Marcel Dekker.

Hajenian, H. G., \& Butler, M. (1980). Inactivation of viruses in municipal effluent by chlorine. Journal of Hygiene (London), 84, 63-69.

Harewood, P., Rippey, S., \& Montesalvo, M. (1994). Effect of gamma irradiation on shelf life and bacterial and viral loads in hardshelled clams (Mercenaria mercenaria). Applied and Environmental Microbiology, 60, 2666-2670.

Hartemann, P., Block, J. C., Joret, J. C., Foliguet, J. M., \& Richard, Y. (1983). Virological study of drinking and wastewater disinfection by ozonation. Water Science and Technology, 15, 145-154.

Herrmann, J. E., Kostenbader, K. D., Jr., \& Cliver, D. O. (1974). Persistence of enteroviruses in lake water. Applied Microbiology, 28, 895-896.

Hewitt, J., \& Greening, G. E. (2006). Effect of heat treatment on hepatitis A virus and norovirus in New Zealand greenshell mussels (Perna canaliculus) by quantitative real-time reverse transcription PCR and cell culture. Journal of Food Protection, 69, 2217-2223.

Heymann, D. L. (Ed.). (2004). Control of communicable diseases manual. Washington, DC: American Public Health Association.

House, C., House, J. A., \& Yedloutschnig, R. J. (1991). Inactivation of viral agents in bovine serum by gamma irradiation. Canadian Journal of Microbiology, 36, 737-740.

Joseph, R. S. (1992). Don't sit on the toilet seat. Journal of Practical Nursing, 42, 12-13.

Koopmans, M. P. G., Cliver, D. O., \& Bosch, A. (Eds.). (2008). Foodborne viruses: progress and challenges. Washington, DC: ASM (American Society for Microbiology Press).

Mandel, B. (1971). Characterization of type 1 poliovirus by electrophoretic analysis. Virology, 44, 554-568.

Mariam, T. W., \& Cliver, D. O. (2000a). Hepatitis A virus control in strawberry products. Dairy, Food and Environmental Sanitation, 20, 612-616.
Mariam, T. W., \& Cliver, D. O. (2000b). Small round coliphages as surrogates for human viruses in process assessment. Dairy, Food and Environmental Sanitation, 20, 684-689.

Mbithi, J. N., Springthorpe, V. S., Boulet, J. R., \& Sattar, S. A. (1992). Survival of hepatitis A virus on human hands and its transfer on contact with animate and inanimate surfaces. Journal of Clinical Microbiology, 30, 757-763.

Mbithi, J. N., Springthorpe, V. S., \& Sattar, S. A. (1991). Effect of relative humidity and air temperature on survival of hepatitis A virus on environmental surfaces. Applied and Environmental Microbiology, 57, 1394-1399.

Mbithi, J. N., Springthorpe, V. S., \& Sattar, S. A. (1993). Comparative in vivo efficiencies of hand-washing agents against hepatitis A virus (HM-175) and poliovirus type 1 (Sabin). Journal of Clinical Microbiology, 59, 3463-3469.

McDonnell, S., Kirkland, K. B., Hlady, W. G., Aristeguieta, C., Hopkins, R. S., Monroe, S. S., et al. (1997). Failure of cooking to prevent shellfish-associated viral gastroenteritis. Archives of Internal Medicine, 157, 111-116.

Mishu, B., Hadler, S. C., Boaz, V. A., Hutcheson, R. H., Horan, J. M., \& Schaffner, W. (1990). Foodborne hepatitis A: Evidence that microwaving reduces risk? Journal of Infectious Diseases, 162, $655-658$.

Nuanualsuwan, S., \& Cliver, D. O. (2002). Pretreatment to avoid positive RT-PCR results with inactivated viruses. Journal of Virological Methods, 104, 217-225.

Nuanualsuwan, S., \& Cliver, D. O. (2003). Capsid functions of inactivated human picornaviruses and feline calicivirus. Applied and Environmental Microbiology, 69, 350-357.

Olivieri, V. P., Hauchman, F. S., Noss, C. I., Vasl, R., Neeper, M. P., \& Cliver, D. O. (1983). Mode of action of chlorine dioxide on selected bacterial and enteric viruses. In M. Butler, A. R. Medlen, \& R. Morris (Eds.), Viruses and disinfection of water and wastewater (pp. 261-281). Guildford, England: University of Surrey Print Unit.

Pagliaro, A. F., Masana, M. O., Sanjurjo, E. D., Fondevila, N. A., \& Rodriguez, H. R. (1995). Foot-and-mouth disease virus inactivation in miniburgers by a continuous dry-moist heat cooking system. Journal of Food Protection, 59, 181-184.

Payment, P., Plante, R., \& Cejka, P. (2001). Removal of indicator bacteria, human enteric viruses, Giardia cysts, and Cryptosporidium oocysts at a large wastewater primary treatment facility. Canadian Journal of Microbiology, 47, 188-193.

Power, U. F., \& Collins, J. K. (1989). Differential depuration of poliovirus, Escherichia coli, and a coliphage by the common mussel, Mytilus edulis. Applied and Environmental Microbiology, 55, 1386-1390.

Power, U. F., \& Collins, J. K. (1990). Tissue distribution of a coliphage and Escherichia coli in mussels after contamination and depuration. Applied and Environmental Microbiology, 56, 803-807.

Rabenau, H. F., Cinatl, J., Morgenstern, B., Bauer, G., Preiser, W., \& Doerr, H. W. (2005). Stability and inactivation of SARS coronavirus. Medical Microbiology and Immunology, 194, 1-6.

Roos, B. (1956). Hepatitepidemi, spridd genom ostron. Svenska Läkartidningen, 53, 989-1003.

Salo, R. J., \& Cliver, D. O. (1976). Effect of acid pH, salts, and temperature on the infectivity and physical integrity of enteroviruses. Archives of Virology, 52, 269-282.

Sattar, S. A., \& Ansari, S. A. (2002). The fingerpad protocol to assess hygienic hand antiseptics against viruses. Journal of Virological Methods, 103, 171-181.

Tree, J. A., Adams, M. R., \& Lees, D. N. (1997). Virus inactivation during disinfection of wastewater by chlorination and UV irradiation and the efficacy of $\mathrm{F}+$ bacteriophage as a 'viral indicator'. Water Science and Technology, 35, 227-232. 
Wang, X. W., Li, J. S., Guo, T. K., Zhen, B., Kong, Q. X., Yi, B., et al. (2005a). Excretion and detection of SARS coronavirus and its nucleic acid from digestive system. World Journal of Gastroenterology, 11, 4390-4395.

Wang, X. W., Li, J. S., Guo, T. K., Zhen, B., Kong, Q. X., Yi, B., et al. (2005b). Concentration and detection of SARS coronavirus in sewage from Xiao Tang Shan Hospital and the 309th Hospital. Journal of Virological Methods, 128, 156-161.

Ward, R. L. (1982). Evidence that microorganisms cause inactivation of viruses in activated sludge. Applied and Environmental Microbiology, 43, 1221-1224.

Ward, R. L., \& Ashley, C. S. (1977a). Discovery of an agent in wastewater sludge that reduces the heat required to inactivate reovirus. Applied and Environmental Microbiology, 34, 681688.

Ward, R. L., \& Ashley, C. S. (1977b). Identification of the virucidal agent in wastewater sludge. Applied and Environmental Microbiology, 33, 860-864.
Ward, R. L., \& Ashley, C. S. (1977c). Inactivation of enteric viruses in wastewater sludge through dewatering by evaporation. Applied and Environmental Microbiology, 34, 564-570.

Ward, R. L., \& Ashley, C. S. (1978). Heat inactivation of enteric viruses in dewatered wastewater sludge. Applied and Environmental Microbiology, 36, 898-905.

Ward, R. L., Ashley, C. S., \& Moseley, R. H. (1976). Heat inactivation of poliovirus in wastewater sludge. Applied and Environmental Microbiology, 32, 339-346.

Warriner, R., Kostenbader, K. D., Jr., Cliver, D. O., \& Ku, W.-C. (1985). Disinfection of advanced wastewater treatment effluent by chlorine, chlorine dioxide and ozone. Experiments using seeded poliovirus. Water Research, 19, 1515-1526.

Widdowson, M.-A., \& Vinjé, J. (2008). Food-borne viruses-State of the art. In M. P. G. Koopmans, D. O. Cliver, \& A. Bosch (Eds.), Food-borne viruses: Progress and challenges (pp. 29-64). Washington, DC: ASM (American Society for Microbiology Press). 